(ISSN - 2752-7018)

VOLUME 02 ISSUE 01 Pages: 1-8

SJIF IMPACT FACTOR (2021: 5. 376)

OCLC - 1276789625 METADATA IF - 7.569
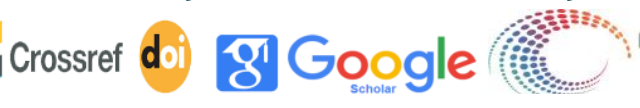

metapata

indexing

5. WorldCat

Publisher: Frontline Journals

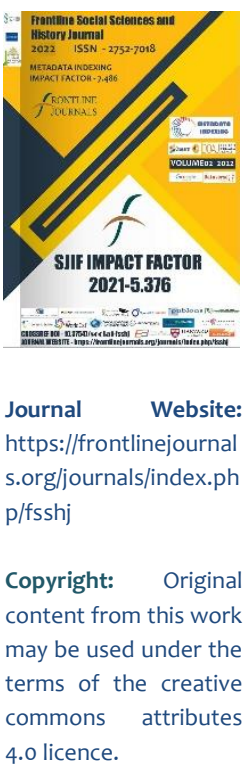

Research Article

\title{
ETHNOTOPONYMS IN THE WORKS OF FOREIGN TOURISTS WHO VISITED CENTRAL ASIA IN THE XIX CENTURY AS A SOURCE IN THE STUDY OF THE SOCIAL STRUCTURE OF THE POPULATION
}

\author{
Submission Date: January 09, 2022, Accepted Date: January 19, 2022, \\ Published Date: January 29, 2022 \\ Crossref doi: https://doi.org/10.37547/social-fsshj-02-01-01 \\ Bekhzodjon I. Zokirov, \\ PhD student,Tashkent State University of Oriental Studies, Uzbekistan
}

\section{Abstract}

This article analyzes the role of ethnotoponyms in the study of the social structure of the population of the Bukhara Emirate, Khiva and Kokand khanates, which are found in "travelogues" created on the basis of travel memoirs of Russian and foreign tourists and officials of the countries visiting Central Asia in the XIX century. We know that ethnotoponyms as a special type of place names reflect the composition of the population of a particular area and the socio-economic processes associated with them, as well as traditions and values.

One of the most important issues of historical toponymy is the comparative analysis of ethnotoponyms on the basis of known sources, the study of the ethnic composition of the population of the region, demographic processes and factors influencing them in terms of sourceology and historiography.From this point of view, the scientific problem studied in this article is to study the social structure and strata of the population of the Central Asian khanates through ethnotoponyms of the region cited in foreign sources to fill some vague gaps not mentioned in local sources.

The main purpose of the study is to recognize the source significance of place names in the study of the social structure of the population of the Bukhara Emirate, Khiva and Kokand khanates, to determine their prestige in society, territorial identity and place in socio-economic life. Given the fact that ethnotoponyms 
(ISSN - 2752-7018)

VOLUME 02 ISSUE 01 Pages: 1-8

SJIF IMPACT FACTOR (2021: 5 · 376)

OCLC - 1276789625 METADATA IF - 7.569

are a multifaceted historical source, it is also intended to provide a scientific basis for their ability to reflect the socio-stratification of society.

The article used research methods such as systematic analysis, chronology, problem-chronological, as well as toponymic stratification, toponymic stratification of place names, genetic analysis, used in historical research.

The study identified the role of travelogues as a common source and the ethnotoponyms in them as an additional source in reflecting the social composition of the population in Central Asia. The place names related to the social structure of the population were classified, the peculiarities of their origin and the theoretical and practical aspects of their study of the socio-economic and ethnic history of the khanate were analyzed.

\section{KeYwordS}

Travelogue, social stratification, khoja, sayyid, eshon, kalandars, dervishes, murid.

\section{INTRODUCTION}

We know that individuals in a society are divided into certain social classes according to their social background, occupation, and prestige and prestige in the area in which they live. At the same time, the strata in society are the main driving force of socio-economic processes, and the development and decline of society depends on the relationship between them. The Bukhara, Khiva and Kokand khanates of Central Asia in the 19th century also had different social strata of the population, and the sources provided a lot of information about their origin, status in society and their legal privileges. In particular, if we look at the sources of this period, one of the distinctive features of the social situation in the region are historical toponyms, through which we can get a lot of information about the social stratification of the population, which is not preserved in written data. Below we analyze some place names related to the social status of the population in the works of Russian and foreign tourists who visited the region. 
(ISSN - 2752-7018)

VOLUME 02 ISSUE 01 Pages: 1-8

SJIF IMPACT FACTOR (2021: 5 · 376)

OCLC - 1276789625 METADATA IF - 7.569

\section{ОBject ANd Methods of RESEARCh}

The article considers the travel memoirs, diaries and published works of Russian and foreign tourists visiting Central Asia in the XIX century as "travelogues" under the general name, and the names of places reflecting their social stratification are selected as the object of study. Historical-chronological and comparative analysis and a systematic approach, as well as toponymic stratification, used in historical research, were used to demonstrate the importance of place names in the study of the social composition of the region.

\section{DiscuSSION AND RESULTS}

The social structure of the population of the Bukhara Emirate, Khiva and Kokand khanates of the XIX century has similarities and differences, the formation of which depends mainly on the origin of the population, property relations, occupations. Research in this area shows that the population of the region is conditionally divided into general "sipoxiy", "ulama", "raiyat" according to social rights and obligations [Makhkamova, 236 ; Normurodova, 218.]. In this case, the composition of the population is aristocratic (sayyid, khoja, eshon); seeders (Uzbeks with their own seed); universally recognized as shagirpesha (Tajik, Persian) and mullahs (educated people) accepted to be based on consideration of the legal factor. These compositions, using their prestige and practice, were able to achieve many privileges in the khanates, for example, property, land, residence in good condition. These aspects are also reflected in the place names, especially in urban areas, where place names are more commonly associated with the khoja, sayyid, eshon, who are considered to be the upper classes and nobles. In particular, in the travelogues of tourists visiting the Emirate of Bukhara, many ethnotoponyms associated with the name of the "master" in the city are mentioned [Meyendorf, 1975; Demezon, 1983; Xanikov, 1851]. Such toponyms come from naming various historical objects, such as caravanserais; Khoja Juibar, Palace Ismail Hodja, Hodja; of the cemeteries: Khoja taband, Khoja Nurabad, Khoja Bulgar, Khoja Turki jandi, Eshan Khoja Khudaydod, Hazrati Eshan Domla, Hazrati Eshan Khabibulla, Khojaasp gardan; of the pools: Podshokhoja pool, Khoja Bulgar pool, Khoja Zayniddin pool, Khoja Kalon pool, Khojatabon pool, Bibi Khalifa pool were toponymically used as names. He also noted that many ethnotoponyms formed from words 
(ISSN - 2752-7018)

VOLUME 02 ISSUE 01 Pages: 1-8

SJIF IMPACT FACTOR (2021: 5 · 376)

OCLC - 1276789625 METADATA IF - 7.569

such as khoja, sayyid, eshan during the study of the country by Russian tourists and military officials of Russia Empire, who visited the Emirate of Bukhara in the 60s and 80s of the XIX century, can be found not only in the names of objects in large cities but also in smaller villages was found. In particular, in the travelogue of A.P.Khoroshkhin in the Kattakurgan branch of Zarafshan district in the name of Yodgorkhoja, Muminkhoja, Khojakurgan, Mullahoja, Boronjoja, Kalandarkhoja, Tursunjoja, Tavakkalkhoja, Khoja karsan, Eshon with Eshon, ethnotoponyms associated with the name, i.e. village names are recorded [Khoroshkhin, 242-254]. In general, the word "Khoja" actually means "great leader" in Persian, but at different times it has specific meanings, and its origin is mainly associated with the Arabs and Islam. However, there is still no consensus or complete scientific conclusion as to which ethnic group or tribe the Arabs belong to. While some scholars associate them directly with the Arab tribes, others believe that the masters were the descendants of Arab generals who conquered Central Asia; there is another view, according to which the lords are one of the four caliphs of the Arab caliphate, or the direct descendants of the prophet [Zagryajisky; 153]. A.A.Semyonov's research supports the third view.
In particular, when the scholar studied the Sayyids of Termez, according to him, the Sayyids were the most influential representatives of the masters, who are directly the descendants of the Prophet [Semenov; 20].

The analysis of the sources shows that the social status of the khoja, sayyid and ishan in different periods has different dynamics, which is related to the role of religion in society. Orientalist N.Khanikov draws attention to the fact that in the state administration of the Bukhara Emirate, two large families of lineage masters - Khoja Sayyid Ota and Khoja Islam Joybari - were superior to the rest in terms of prestige [Khanikov, 182]. At the same time, during the khanate period, there are more and more people claiming that they are masters because of the large number of privileges given to them in the society. As a result, the requirement that they have their own family tree genealogy further increased their prestige. According to the lineage of the official sayyids, they were called "siyodatpanoh" (defender of the honor of sayyids), and the masters were called "isolatpanoh" (defender of the high lineage) [Normuradova; 72]. According to H.Vamberi, the Eshans were the leaders and coaches of the Muslim community and were considered 
(ISSN - 2752-7018)

VOLUME 02 ISSUE 01 Pages: 1-8

SJIF IMPACT FACTOR (2021: 5 · 376)

OCLC - 1276789625 METADATA IF - 7.569

religious leaders in the Sufi world [Vambery; 87]. These population groups had a unique prestige and prestige within the nation and enjoyed many socio-economic benefits. Especially among the locals, the fact that whoever is not a murid of an ishan means that he is not a Muslim indicates that they have a special place in the territory of the emirate. Later, when the socio-political meaning of the words khoja and eshan was forgotten, they began to be used in relation to the ethnic name and the common name of certain groups of people, or preserved in place names.

In the Central Asian khanates there are other population groups belonging to the middle and lower classes, which can be seen from the place of residence, socio-historical objects they own, that they are inferior to the khoja, sayyids and eshans in terms of prestige. In particular, the researches of I.Virskiy and N.Sityankovsky, who studied the Zarafshan valley, noted place names such as Kalandar, Qalandarkhoja, Beklar, Boylar, Raboti Goziyon, Darvishan, who named different district villages [Virsky, 1876; Sityankovskiyb 1900]. Also, in his diaries, the American traveler Yu. Skyler, who visited Central Asia in the 80s of the 19th century, noted that he was in a neighborhood called Kalandarkhana, consisting of several mosques and a series of rooms near the Mulla Gate in Samarkand [Schuyler, 257]. He added that the neighborhood was inhabited by several dervish communities and kalanders, who were mainly allowed to beg in the cities but were forbidden to pray. According to A.Vambery, 2 miles from Khiva there is a village called Kalandarkhana [Vambery, 146]. The author adds that the village of Kalandarkhana in Khiva was almost identical to the village of the same name in Kokand, both of which were inhabited by a relatively small group of dervishes. G. Lansdale also writes that during his visit to the Kokand khanate, he passed through the village of Devona on his way back to Kokand in Margilan. He says that this village consists of several ruined huts, the name of which corresponds to the dervishes and devons who lived here [Lansdell, 269].

It is noteworthy that in the general layer of place names in the works of Russian and foreign authors who visited Central Asia in the XIX century, place names that reflect the social status of the population may also appear as a result of a certain historical process. In particular, G.I. Danilevsky notes that on the way from Khiva to Hazarasp, 22 versts from Khiva, there is the village of Beveten [Danilevsky, 115]. We know 
(ISSN - 2752-7018)

VOLUME 02 ISSUE 01 Pages: 1-8

SJIF IMPACT FACTOR (2021: 5. 376)

OCLC - 1276789625 METADATA IF - 7.569

that the bevatan was a farming group that rented state lands in the Khiva khanate and lived in different parts of the khanate. During the XIX century, as a result of the allocation of lands along the Shahmurad and Khanabad canals to many bevatans by the Khiva khans, large and small villages were formed along the khanate. As a result of the use of this stratum in the development of neglected lands in Khiva, the emergence of place names associated with their names in the developed areas arose precisely in connection with the historical process of a certain period.

\section{Conclusions AND hypotheses}

In conclusion, it should be noted that such place names mentioned in travelogues, although not purely ethnotoponyms, are accepted as relative ethnotoponyms because they reflect the general social status of the population in a particular area. Such place names name many settlements in the cities of the khanate, which in a sense reflect the socio-historical topography of the region, its role and prestige in the socio-economic life of the state. Ethnotoponyms related to the social status of the population are based on the names of rich people, the ruling class and the influential strata of society, such as Sayyids, Khojas, Beklar. given by the upper class, it expressed elements of meaning such as isolation from society, contempt. Also, place names such as Bevatan, Chorikor, Jarmshi also refer to the social status of the population and they were formed as a result of socio-political processes in a certain historical period.

\section{REFERENCES}

1. Danilevskiy I. Opisaniye Xivinskago xanstva. -Sankt-Peterburg, 1851. -S. 115.

2. Eugene Schuyler. Turkistan notes of journey in Russian Turkistan, Khokand, Bukhara, and Khuldja. New York, 1876. -P. 411.

3. Henry Lansdell. Russian Central Asia (including Kuldja, Bokhara, Khiva and Merv). Vol. 1. -London. 1885. -P. 687.

4. Makhkamova N.R. Sotsialnaya struktura obshestva na territorii Uzbekistana: traditsii i transformatsii (konets XIX v. - 30 -e godi XX v.). -Tashkent: Aloqachi, 2009. -S. 236

5. Meyendorf Ye.K. Puteshestviye iz Orenburga v Buxaru. - M.: Nauka, 1975. S. 183. 
(ISSN - 2752-7018)

VOLUME 02 ISSUE 01 Pages: 1-8

SJIF IMPACT FACTOR (2021: 5. 376)

OCLC - 1276789625 METADATA IF - 7.569

Publisher: Frontline Journals

6. Normurodova G. Social stratification of the Emirate of Bukhara and the role of the population in society. (1868-1920). -T .: Navruz, 2019. -P. 218.

7. Sityankovskiy N.F. Zametki o Buxarskoy chasti dolinы Zerafshana//Izvestiya Turkestanskago otdela IRGO. Tom' I, vыpusk' II. -Tashkent: Tipo-litografiya Br. Portsevыx', 1900. -S. 121-314.

8. Semenov A.A. Proisxojdeniya Termezskix seyidov i ix drevnyaya usipalnitsa "Sultan Sadat.//PTKLA. T. XVIII. -Moskva, 1914. S. 342 .

9. Tursunov N.N. Ethnic characteristics of the population of the Southern Surkhandarya oasis. Phd. diss. hist. scien.-Tashkent, 2007. -S. 202.

10. Vambery A. Travels in Central Asia. London, 1864. -P. 443.

11. Virskiy I. Staticheskaya svedeniya o Zerafshanskom' okrug: etnograficheskiy, selsko-xozyaystvenniy i obщesoslovny sostav' naseleniya okruga za 1872 god'.//Turk sbornik. Tom 123. -SpB, 1876. -S. 333-434.;

12. Xanikov N.V. Opisaniye Buxarskago xanstva. - SPb., 1843. - S. 286.
13. Xoroshxin A.P. Sbornik' statey kasayushixsya do Turkestanskogo kraya. Spb., 1876. -S.533.

14. Zagryajiskiy G.Yuridicheskiye obichai kirgiz, o razlichnix rodax sostoyaniyi o pravax, imi prisvoyennыx//Materiali dlya statistiki Turkestanskago kraya. Vip. 4. Spb., 1876. -S.153

15. Zapiski o Buxarskom xanstve (Otcheti P. I. Demezona i I. V. Vitkevicha). - M.: Nauka, 1983. - S. 154.

16. Zokirov, B. I. U. (2021). Works of foreign tourists visiting Central Asia in the XIX century as a source in the study of regional ethnotoponyms. CURRENT RESEARCH JOURNAL OF HISTORY (2767-472x), 2(10), 33-38.

17. Doniyorov, A. K. (2020). Problems of Ethnogenesis and Ethnic History of Uzbek People at the Current Stage. PalArch's Journal of Archaeology of Egypt/Egyptology, 17(6), 8968-8974.

18. Khudoyberdiyevich, D. A. (2018). On general methodological, ethnopolitical and ethnocultural aspects of "Diaspora issues"(To the theoretical formulation of the problem and the ways of its practical solution). ACADEMICIA: An International 
(ISSN - 2752-7018)

VOLUME 02 ISSUE 01 Pages: 1-8

SJIF IMPACT FACTOR (2021: 5 . 376)

OCLC - 1276789625 METADATA IF -7.569

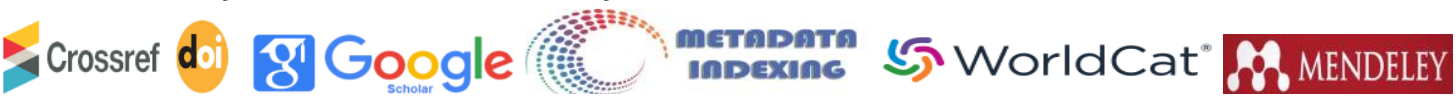

Publisher: Frontline Journals

Multidisciplinary Research Journal, 8(11),

68-74. 